\title{
BERTEOLOGI DENGAN SUARA HATI \\ (SUATU PENDEKATAN PASTORAL BAGI PENCANDU NARKOBA)
}

\author{
Robinson Simanungkalit \\ Institut Agama Kristen Negeri Tarutung \\ Email: aristo_simanungkalit@yahoo.co.id
}

\begin{abstract}
Abstrak : Peran gereja yang menggarami dan menerangi masyarakat seharusnya menempatkan gereja sebagai kelompok terdepan dalam tugas pastoral sosialnya. Gereja sebagai institusi keagamaan dan institusi sosial tentu diharapkan sumbangsihnya terhadap persoalan-persoalan sosial masyarakat. Kesalehan religius seharusnya bergandegan dengan kesalehan sosial. Kesalehan religius dan kesalehan sosial tidak bisa dilepaskan dari peranan suara hati gereja sebagai komunitas religius terhadap persoalan-persoalan yang terkait dengan eksistensi suara hati pada komunitas yang lain.
\end{abstract}

\begin{abstract}
The role of the church as to be salt and light in society are supposed to place herself as the foremost assembly in her pastoral duty. Church as the religious and social institution is highly expected to contribute to all the issues emerged in society. Her religious piety should be in line with her social dovoutness. These two virtues are unattached from the church's conscience roel as a religios community towards the problems associated with the exixtence of the conscience of other communities.
\end{abstract}

Kata Kunci : Suara hati, Pecandu Narkoba, Pelayanan Pastoral, Relevan, Kontekstual

\section{Latar Belakang Masalah}

Pada konteks kehidupan sekarang ini semakin banyak orang yang merasa hatinya tidak lagi tentram, tenang dan nyaman. Tidak hanya di kota-kota besar yang penduduknya gaya hidupnya sangat hedonis dan konsumtif, bahkan pola hidup yang sama juga sudah merambah samai ke pelosok desa. Pola hidup yang hedonis dan konsumtif ini menjadi salah satu pemicu maraknya peredaran narkoba. "Saat ini banyak generasi muda yang mengikuti gaya teman-temannya dengan cara mengkonsumsi narkoba, dari yang awalnya coba-coba, diberi gratisan, akhirnya keterusan dan jadi ketergantungan," ungkap Kepala seksi Media Elektronik BNN, Diah Hariani pada acara Focus Group Discussion (FGD) dengan pemuda kelurahan Harjamukti Cimanggis, Depok, Kamis (30/10/2014). Menurut Diah, narkoba adalah isu yang kritis dan rumit yang tidak bisa diselesaikan oleh hanya satu pihak saja. Karena narkoba bukan hanya masalah individu namun masalah semua orang. Mencari solusi yang tepat merupakan sebuah pekerjaan besar yang melibatkan dan memobilisasi semua pihak baik pemerintah, lembaga swadaya masyarakat (LSM) dan komunitas lokal. ${ }^{1}$

Besarnya jumlah penyalah guna narkoba di Indonesia menunjukkan kondisi darurat narkoba. Angka prevalensi pengguna narkoba di Indonesia pada survey tahun 2015 mencapai $2.20 \%$ atau lebih dari 4 juta orang. Dari jumlah itu $22 \%$ diantaranya adalah pelajar dan mahasiswa. Kondisi ini sungguh sangat mengkhawatirkan karena akan mengancam kelangusangan hidup generasi selanjutnya ${ }^{2}$ Pada Tahun 2018, Angka-angka tersebut bergegrak pada 40.553 kasus narkoba yang diungkap BNN dimana kasus-kasus tersebut melibatkan 53. 251 tersangka. Artikel ini telah tayang di Kompas.com dengan judul "BNN: Sepanjang 2018, 2 Juta Mahasiswa dan 1,5 Juta Pekerja Terlibat Narkoba",."

1 https://news.okezone.com/read/2014/10/31/338/1 059246/narkoba-kini-jadi-gaya-hidup-pemuda 2 https://jurnal.uns.ac.id/habitus/article/view/1886 $0 / 14964$, hal 92

3 https://megapolitan.kompas.com/read/2019/03/2 5/10215681/bnn-sepanjang-2018-2-juta- mahasiswadan-15-juta-pekerja-terlibat-narkoba. 
Bagi penulis, gambaran diatas memperlihatkan adanya sebuah permasalahan yang berkaitan dengan suara hati. Kecenderungan kemerosotan moral karena mengabaikan suara hati dan menutupi dosa dan membenarkan diri atas apa yang sedang terjadi. Kondisi kecanduan juga menyebabkan mereka sulit untuk terlepas dari jerat narkoba. Memutuskan untuk menerima layanan rehabilitasi pun sangat sulit apalagi untuk membuat keputusan berhenti mengkonsumsi narkoba. Semua permasalahan tersebut berkaitan dengan peranan suara hati yang ada di dalam diri mereka. Karenanya, pendampingan pastoral menjadi salah satu upaya untuk menolong mereka ${ }^{4}$ Relevansi pelayanan/pendampingan pastoral bagi pecandu narkoba dengan melihat peranan suara hati dalam diri setiap orang akan diteliti dengan metode penelitian kwalitatif deskriptif. Tujuan dari penelitian ini adalah memperkaya khasanah bertelogi secara pastoral terhadap isu-isu dan kontekskonteks kehidupan ada di sekitar gereja dengan berorientasi kepada peranan suara hati.

\section{Beberapa Defenisi Suara Hati \\ Dalam Bahasa Inggris}

Philip Babcock,dkk

menjelaskan arti dari suara

(ed) (conscience) sebagai suatu perasaan benar atau tidak benar dalam diri seseorang untuk memutuskan suatu hal berdasarkan sikap diri sendiri, tujuan atau karakter dibarengi dengan perasaan untuk berbuat atau bertindak sebagai sesuatu yang benar atau salah. Pemahaman yang lain dari suara hati adalah suatu kekuatan atau kuasa atau prinsip yang mengarahkan seseorang kepada tindakan yang benar dan jauh dari kesalahan. ${ }^{5}$ Consience juga diartikan sebagai Pengetahuan dalam batin, pikiran yang terdalam, pengetahuan atau pengenalan terhadap sesuatu dari dalam hati. Pengetahuan dalam hati akan kualitas moral, motif dan tindakan sendiri yang meliputi perasaan benar atau salah dalam melihat

\footnotetext{
${ }^{4}$ Charles V Gerkin, Konseling Pastoral dalam Transisi, BPK Gunung Mulia-Kanisius :1999, 9-15 ${ }^{5}$ Philip Babcock Gove (ed), Webter's Third New International Dictionary Of The English Language Unabridge, Springfield, USA : G \& C Meriam Company, 1996, hal 428
}

sesuatu yang harus dipertanggungjawabkan sendiri dan suatu kemampuan atau prinsip yang menyatakan kualitas moral akan tindakan menyetujui yang benar dan menyalahkan yang salah ${ }^{6}$. Dari beberapa pemahaman yang diuraikan diatas maka bebera pa hal yang bisa dipahami sebagai suara hati (consience) dalam bahasa Inggris adalah. Pertama, suara hati adalah pengetahuan di dalam batin untuk membedakan tindakan yang benar dan salah secara moral. Kedua, suara hati adalah kemampuan moral yang mengarahkan manusia untuk menyetujui yang benar dan menyalahkan yang salah.

\section{Dalam Bahasa Latin}

Kata conscince dalam bahasa inggris berasal dari bahasa latin "conscientia" yang merupakan kata gabungan dari akar kata "con" yang berarti dengan atau bersama dan kata "scio" yang berarti mengetahui atau mengerti. Jadi consientia berarti "to know together" (mengetahui bersama), atau "joint knowledge with others" (pengetahuan bersama dengan orang lain) atau "the knowledge we share with another" (pengetahuan yang kita bagi dengan orang lain). ${ }^{7}$

\section{Dalam Bahasa Yunani}

Kata "conscientia" dalam bahasa latin berasala dari bahasa Yunani yaitu $\sigma v v \varepsilon i \delta \eta \sigma l \varsigma$ (suneidesis) yang berasal dari kata $\sigma v v$ yang artinya "dengan", "bersama dengan", "oleh" atau "melalui", dan bentuk infinitif dari ol $\delta \alpha$ yang artinya "tahu", "mengerti", "mengenal", "menghormati”, "ingat". Jadi $\sigma v v \varepsilon l \delta \eta \sigma l \varsigma$ (suneidesis) dalam bahasa Yunani mengandung pengertian mengetahui bersama atau mempunyai pengetahuan bersama dengan orang lain. ${ }^{8}$ Dalam terminologi bahasa Yunani, suara hati dibedakan dalam beberapa pengertian. Ada suara hati yang baik, suara hati tanpa

\footnotetext{
${ }^{6}$ The Compact Edition of the Oxford English Dictionary, Vol.I, (Oxford: the Oxford University Press, 1971, hal 845

7 Alfred M.Rehwinkel, "conscience" dalam everett F, Harisson (Ed), Bakers's Dictionary of Theology, (Michigan: Baker Book House, 1985), hal. 136

${ }^{8}$ Newman JR, Barclay M, Kamus YunaniIndonesia, Jakarta : BPK Gunung Mulia, 1993,48, 115
} 
salah, suara hati yang jahat, dan suara hati yang murni.

\section{Dalam Bahasa Indonesia}

Hasan Shadily, dkk (ed) menjelaskan suara hati sebagai pati terdalam dan tersuci bagi manusia yang berseru kepadaNya untuk bercinta serta melakukan yang baik dan mengelakkan yang jahat. Suara hati mengungkapkan hukum yang dipenuhi dalam cinta akan Allah dan sesama manusia. Shadily membedakan suara hati dengan hati nurani dan kata hati. Hati nurani lebih menekankan tanggapan, tingkah laku suatu kelompok sosial dan kata hati menekankan bahwa pendidikan dapat mengubah kata hati. ${ }^{9}$ Arimurthy menjelaskan suara hati sebagai adanya kesadaran hidup manusia yang dapat membedakan antara keinginan dari hawa nafsu dan cetusan kehendak dari sumber yang luhur yaitu cahaya budi, tuntutan suci dari Tuhan yang Maha Esa. ${ }^{10}$ Maka dapat disimpulkan bahwa suara hati ada di dalam batin terdalam manusia yang mengungkapkan bahwa di dalam hati manusia ada suara yang kecil yang mengarahkan manusia untuk melakukan yang baik dan mengelakkan yang jahat. Suara hati juga mengungkapkan hukum cinta kasih kepada Allah dan sesama manusia. Dari beberapa perbandingan kata dalam pendekatan berbagai bahasa penulis melihat bahwa istilah suara hati adalah adalah istilah yang menonjolkan adanya pengetahuan atau kesadaran di dalam batin manusia. Jadi suara hati juga bisa dipahami sebagai kesadaran hati, pengetahuan hati bertindak sebagai petunjuk bagi setiap orang untuk menilai sesuatu yang baik atau tidak baik untuk dilakukan.

\section{Perbedaan Makna dan Peranan Suara Hati}

\section{Dalam Perjanjian Lama}

Dalam Perjanjian Lama memang tidak ada kata yang khusus untuk menyebut suara hati/hati nurani. Namun demikian fenomena dari fungsi suara hati itu sendiri banyak terlihat. Perjanjian lama menyatakan

\footnotetext{
${ }^{9}$ Hasan Shadily, dkk (ed) dalam Ensiklopedi Indonesia Vol.6 (Jakarta: PT Ichtiar BaruVan Hoeve, t.th) hal 3336

${ }^{10}$ Arimurthy, Hati Suci, Hati Nurani, dalam Ensiklopedi Nasional Indonesia,
}

bahwa pengetahuan akan yang baik dan yang jahat hanya ada dalam mengingat dan memelihara hukum Turat Allah (Mazmur 16:7-8, 4:9, 119:11-12). Dalam Perjanjian Lama lebih banyak terdapat penghakiman yang dari dalam yaitu di dalam hati manusia. ${ }^{11}$

1. Adam dan Hawa yang telah melanggar perintah Allah itu melarikan diri dari hadirat Allah dan bersembunyi karena ketakutan ( Kej. 3:7-8)

2. Kain yang telah membunuh adiknya Habel diliputi suasana ketakutan (Kej.4:14)

3. Anak-anak Yakub yang telah berbuat kejahatan terhadap Yusuf saudaranya itu merasa malu atas apa yang telah pernah diperbuatnya terhadap Yusuf (Kej. 42:21)

4. Hati Daud berdebar-debar setelah ia memotoong punca jubah Saul (1 Sam 24:6, 2 Sam. 24:10)

5. Pemazmur melukiskan betapa menderitanya dirinya sebelum membereskan kesaahannya dan dosanya di hadapan Tuhan (Mazmur 32:1-5). Hal ini dsebabkan karena penghakiman hatinya sedang bertindak. Pada umumnya peranan suara hati/hati nurani dalam Perjanjian Lama adalah memegang peranan penting.

\section{Dalam Perjanjian Baru}

Dalam Perjanjian Baru banyak dijumpai istilah "suara hati". Suara hati merupakan kemampuan untuk menentukan apa yang benar dan salah secara pribadi. Ada beberapa permasalahan yang muncul dalam Perjanjian Baru tentang suara hati.

1.Bagaimanakah status suara hati di dalam diri manusia, di satu pihak suara hati ada di dalam manusia yang tidak terpisahkan dari manusia itu sendiri (Roma 2:15) namun di pihak lain suara hati merupakan suatu kuasa yang terpisah dari manusia (Roma 9:1).

2. Bagaimanakah peranan suara hati di dalam manusia, di satu pihak suara hati berfungsi sebagai penilai tindakan benar

\footnotetext{
${ }^{11}$ H.Soekahar, Hati Nurani, Malang: Penerbit Gandum Mas, 1989, hal 29-31
} 
dan salah pada masa lalu dan sekarang, namun di pihak lain suara hati berfungsi sebagai penuntun apa yang akan dilakukan pada saat-saat yang akan datang. Rasul Paulus melihat bahwa norma suara hati ditentukan oleh perintah - perintah Allah melalui Wahyu dan bukan moral secara bebas. ${ }^{12}$

\section{Dalam Sejarah Gereja}

Istilah dan fenomena suara hati atau hati nurani juga dilihat dalam sejarah gereja. Seiring dengan munculnya pemahaman hati nurani menurut tokohtokoh dalam sejarah gereja menimbulkan beberapa permasalahan tentang arti dan peranan suara hati. Sebelum zaman Reformasi, pengajaran mengenai suara hati/hati nurani sudah kelihatan. Aureius Augustinus (354-430 SM) berbicara mengenai conscientia dalam hubungan dengan catatan hukum yang kekal yang tertulis dalam hati (Enar.in Ps.27:1). Melalui hati nurani, Augustinus dapat melihat Allah yang menciptakannya. Augustinus cenderung memusatkan perhatiannya pada ide mengenai kesadaran yang menguji dan menghakimi tindakan moral. Hubungan suara hati dengan kesadaran lebih umum mulai nampak dari Augustinus. Yohanes Crysostom (347-407) uskup Costantinopel menggambarkan bahwa suara hati sebagai sumber pengertian moral yang tidak bergantung pada apapun. Sama seperti alam semesta, Chrysostom melihat bahwa melalui hati nurani pikiran manusia dapat membaca mengenai Allah. Bernard dari Clair Vauk (1090-1153) pemimpin gereja yang amat aktif dari abad ke 12 melihat bahwa dalam hati nurani ada penghakiman yang tak dapat dirusakkan. Ia sangat menekankan kehidupan yang ada di dalam. Berbeda dengan teologi gereja yang hanya mementingkan apa yang kelihatan atau yang tampak di luar saja. ${ }^{13}$

Thomas dari Aqunias (1225-1274) sangat menekankan aspek intelektual hati nurani. Aquinas memandang hati nurani sebagai pikiran yang melakukan

\footnotetext{
12 Hans Conzelman, An Outline of the Theology of New Testament, London :SCM Press Ltd, 1968/1969, hal 82

${ }^{13}$ Soekahar, Hati Nurani, Flores: Penerbit Nusa
}

penghakiman moral. Aquinas membedakan Synderesis dengan Conscientia sebagai elemen dari hati nurani. Synderesis merupakan rabun intuitif dari prisnsipprinsip utama yang berakar dalam hukum alami sedangkan Conscientia merupakan penerapan hukum-hukum ini dalam perbuatan-perbuatan tertentu. Synderesis tidak dapat berbuat kesalahan sedangkan Conscientia dapat berbuat kesalahan. ${ }^{14}$

Dalam zaman Reformasi, hati nurani juga menjadi suatu hal yang penting dan banyak dibicarakan. Bagi Martin Luther (1483-1546), suara hati memegang peranan yang sangat penting. Hal itu terlihat ketika Martin Luther memberikan jawaban pada persidangan di Worms :

"Unless $i$ am convinced by the testimony of the scripture or by clear reason (for I do not trust eihter in the pope or in councils alone, since it is well known that they have often erred and contradicted themselves). I am bound by the scriptures I have quoted and my conscience is captive to the word of God. I cannot and I will not retract anything, since it is neither safe nor right to go against conscience. ${ }^{15}$ (kecuali kalau saya diyakinkan oleh kesaksian kitab suci atau oleh alasan yang jelas (karena saya tidak percaya lagi dengan Paus dan konsilinya, sejak semuanya telah mengetahui bahwa mereka sering berbuat salah dan sering bertentangan), saya dibatasi oleh kitab suci yang telah saya percayai dan suara hati saya ditawan oleh firman Allah. Saya tidak dapat dan tidak akan menarik kembali pandangan saya karena tidaklah baik atau benar menentang suara hati.

Hal ini memperlihatkan bahwa bagi Luther suara hati identik dengan suara Allah yang tidak dapat dielakkan dalam diri setiap manusia. Suara hati tidak netral tetapi juga tidak otonom. Suara hati selalu diperebutkan oleh Allah dan iblis. Jadi bukan otonom sebagai pusat kepribadian sesesorang. Suara hati selalu dibimbing dan suara hati menjadi bebas hanya setelah Allah

\footnotetext{
14 John Macquarrie, "Conscience" A Dictionary of Christian Ethics, London :SCM Press Ltd. 1984, hal 66

${ }^{15}$ Bernard Lohse, Martin Luther : An ntroduction to His Life and Work, Philadelphia : Fortress Press, 1986, hal 161
} 
membebaskan dan menangkapnya. ${ }^{16}$ Yohanes Calvin (1509-1540) mengatakan bahwa suara ati adalah pengantara antara Allah dan manusia. Manusia tidak dibiarkan memendam dalam dirinya sendiri apa yang diketahuinya. Suara hati mengejarnya sampai ia mengakui kesalahannya. Hukum mengikat hati nurani karena seseorang diikatnya tanpa memandang atau mempehitungkan orang-orang lain. Maka barangsiapa tidak sopan perilakunya dia tidak hanya berdosa karena memberi contoh yang buruk kepada saudara-saudaranya tetapi hati nuraninya juga bersalah kepada Allah. Calvin menekankan bahwa hanya prinsip-prinsip dari hati nurani adalah tertuju kepada Allah bukan kepada peraturan-peraturan. ${ }^{17}$

\section{Dalam Pandangan Modern}

Dalam sudut pandang modern arti dan peranan suara hati juga berbeda-beda dan seolah-olah bertentangan. Bagi Jean Jacques Rousseau (1712-1778), peranan suara hati nampaknya begitu lemah. Rousseau melihat bahwa hati nurani alamiah hanyalah merupakan kepekaan yang memimpin pada moralitas dan tidak berisi hal-hal yang salah atau hal-hal yang wajib. Sementara bagi Immanuel Kant (1724-1804) suara hati memiliki peranan yang sangat besar. Ketika Kant meninggal dunia, di batu nisannya dituliskan " hanya ada dua hal yang semakin menakutkan di sepanjang hidupku yaitu : langit yang berbintang terus berkelip-kelip dan hati nurani yang terus bersuara di dadaku, yang terus mengeluarkan perintah kepadaku. Menurut Kant tuntutan moral pada diri manusia disebut categorial imperartive. Tuntutan itu mutlak tidak bergantung dari untung, manfaat atau nikmat pribadi dan nikmat sosial apapun. ${ }^{18}$

Sigmund Freud (1856-1939) dalam perspektif psikoanlisis menyebut bahwa peranan suara hati kurang begitu besar. Bagi Freud hati nurani tidak ada dan belum

\footnotetext{
${ }^{16}$ Heiko A. Oberman, Luther : Man between God and Devil, New Haven, London: Yale University Press, 1989, hal 203-205

17 Yohanes Calvin, Intitutiom Jakarta:

BPK Gunung Mulia, 1985, hal 209

${ }^{18}$ Stephen Tong, Roh Kudus, Suara Hati
}

terdapat pada permulaan hidup seseorang.Yang disebut hati nurani sebenarnya disodorkan kepada seseorang oleh masyarakat yang percaya secara apriori adanya hati nurani. Memang Freud bukan ingin menjelaskan pengertian hati nurani. Freud menjelaskan peranan super ego yang dimengerti sebagai dasar psikologis bagi fenomena etis yang disebut hati nurani. ${ }^{19} \mathrm{Di}$ sisi yang lain, seorang ahli ilmu perilaku dan otak yang bernama Daniel Goleman megadakan penelitian yang menggemparkan yang memberikan tempat yang begitu besar untuk suara hati. Goleman mengatakan bahwa: Dalam mengambil keputusan-keputusan yang amat menentukan nasib kita selanjutnya, misalnya dalam mengejar karier, apakah bertahan pada pekerjaan yang aman-aman saja atau siapa yang akan diajak menikah dan lain-lain, tidak dapat dibuat dengan sebaik-baiknya hanya dengan rasionalitas tetapi membutuhkan suara hati.

Suara Hati dan Pelayanan Pastoral Bagi Para Pencandu Narkoba

Peran gereja yang menggarami dan menerangi masyarakat seharusnya menempatkan gereja sebagai kelompok terdepan dalam tugas pastoral sosialnya. Gereja sebagai institusi keagamaan dan institusi sosial tentu diharapkan sumbangsihnya terhadap persoalanpersoalan sosial masyarakat. Kesalehan religius seharusnya bergandegan dengan kesalehan sosial. Kesalehan religius dan kesalehan sosial tidak bisa dilepaskan dari peranan suara hati gereja sebagai komunitas religius terhadap persoalan-persoalan yang terkait dengan eksistensi suara hati pada komunitas yang lain. Gereja seharusnya hadir untuk semua dan berkarakter iklusif dalam peran sosialnya. Gereja harus membawa kemaslahatan bagi semua melalui prinsip kebaikan umum. Gereja perlu mengembangkan sikap solider terhadap persoalan-persoalan sosial yang akan menjadikan gereja sebagai penopang kohesi sosial masyarakat. Peran gereja yang menggarami dan menerangi masyarakat (Matius 5:13) seharusnya menempatkan

\footnotetext{
${ }^{19}$ K.Bertens, Etika , Jakarta: Penerbit PT Gramedia Pustaka Utama, 1993, hal 7475
} 
gereja sebagai kelompok terdepan dalam tugas pastoral sosialnya. ${ }^{20}$

Problema sosial dan spiritual yang dihadapi oleh pemakai narkoba memang sulit diatasi. Sulit bagi mereka untuk mengambil keputusan melepaskan diri dari pengaruh Narkoba. Sulit, tapi bisa dilakukan. Dan para pengguna narkoba ini perlu bantuan tidak hanya dari diri sendiri, melainkan juga dari pihak luar. Pihak luar meliputi, keluarga, lingkungan sekitar, Panti Rehabilitas, Psikiater, lingkungan baru yang telah bersih dari narkoba (juga teman-teman) - dukungan sebaya dan faktor pendukung lainnya (dalam hal ini juga gereja dan para pekerja pastoral). Seiringnya berjalan waktu, pikiran mereka telah otomatis melakukan tindakan tersebut tanpa kesadaran ${ }^{21}$ mereka dan menjadi suatu kebiasaan. Di dalam otak manusia terdapat memori, sebuah proses mental yang memungkinkan manusia untuk memperoleh, menyimpan, dan mengeluarkan informasi. Di dalam memori pemakai narkoba telah melekat betapa nikmatnya rasa zat tersebut. Hal inilah sumber pendukung para pengguna narkoba sulit berhenti. Banyak dari mereka pun mengalami krisis kepercayaan diri, karena ketika menggunakan narkoba, kepercayaan diri mereka meningkat, bahkan tidak peduli terhadap sekitarnya, kecuali disaat mereka berada di lingkungan bukan pemakai narkoba. Selain kepercayaan diri, mereka juga kerap mengalami anger, emosi tinggi, sensitif, sedih, self pity, belum menerima kenyataan, masalah relationship, bosan akan hidup yang "datar", tidak sabar, takut melakukan tindakan yang salah atau bisa jadi menganggap semua orang salah, tidak baik, hanyalah dirinya yang benar, kesepian, dan masih banyak lagi. ${ }^{22}$

\footnotetext{
${ }^{20}$ Sudarno Sumato, Dalam Sekilas Tentang Pelayanan Pastoral Di Indonesia, Jakarta: Majelis Jemaat GKI Menteng Jakarta, 2010, hal, 6-8

${ }^{21}$ Kesadaran inilah yang secara teologis dipahami sebagai eksistensi dari suneidesis atau suara hati/hati nurani yang membimbing seseorang untuk mengetahui baik atau tidak baiknya sebuah tindakan.

22 https://www.kompasiana.com/sn/54f7ce33a33 $3112 \mathrm{~b} 6 f 8 \mathrm{~b} 4 \mathrm{ecc} / \mathrm{mengapa-pecandu-narkoba-}$
}

$\begin{array}{rcr}\text { Setiap } & \text { orang pasti sering } \\ \text { diperhadapkan } & \text { dengan pengambilan }\end{array}$ keputusan Etis (yang seharusnya). Setiap pengambilan keputusan haruslah melalui sebuah proses dan pertimbangan yang matang. Dalam pertimbangan pengambilan keputusan ini suara hati (Suneidesis) memiliki peranan yang sangat besar. Suara hati berperan untuk memberikan penilaian tentang baik atau tidak baiknya (jahatnya) sesuatu atau suatu tindakan. Apakah suara hati mampu menujukkan jalan keluar ketika seseorang hendak memutuskan sesuatu? Atau pertanyaan konkretnya adalah, apakah suara hati mampu menolong para pecandu narkoba untuk dipulihkan? Sebenarnya, jika pengetahuan yang ditawarkan oleh suara hati/hati nurani diperiksa secara jujur, kita (dan juga mereka) akan sampai pada keinsyafan akan kelambanan moral yang membelenggu keinginan dan kenikmatan daging yang sesaat. ${ }^{23}$

Suara hati menjadi kesadaran praktis akan hubungan pribadi dengan Allah dan sesama yang membimbing setiap orang untuk menyadari setiap tindakan yang dilakukan. Suara hati juga bersaksi setelah seseorang melakukan suatu tindakan yang benar atau salah. Melakukan suatu tindakan yang dimaksud juga meliputi sikap, katakata dan pikiran seseorang. Hasil penilaian ini menentukan hal-hal yang akan dilakukan kemudian. Ketika seseorang mengingat kembali semua pikiran, tindakan, sikap, perbuatan dan yang lainnya maka sebenarnya suara hati sedang mencoba memberi kesaksian yang tepat tentang bagai mana seseorang harus memenuhi standarnya Allah. Karena itu kepekaan untuk mendengarkan suara hati harus diupayakan oleh setiap orang. Namun hanya sedikit orang yang mencapai tahap akan merasa penyesalan yang mendalam dengan mengutuk dirinya karena mengikuti keyakinan moralnya sendiri ${ }^{24}$

Terkait dengan hal di atas, salah satu alat pelayanan gereja yang dapat dipakai untuk merespons masalah-masalah

\footnotetext{
${ }^{23}$ Verne H.Fletcher, Lihatlah Sang Manusia, Suat Pendekatan Dasar pada Etika Kristen Dasar, Jakarta: BPK Gunung Mulia, 2007, 48-49

${ }^{24}$ K.Bertens, Etika , Jakarta: Penerbit PT Gramedia Pustaka Utama, 1993, hal 74-75
} 
tersebut adalah pelayanan pastoral. Dengan mempraktikkan pelayanan pastoral yang relevan dan kontekstual gereja diharapkan dapat merespons berbagai masalah kemanusiaan termasuk keberadaan para pecandu narkoba secara bertanggungjawab. Pelayanan pastoral relevan/kontekstual adalahpelayananpastoral yang memungkinkan gereja memberikan respons yang tepat dan utuh atas berbagai masalah yang sedang terjadi di tengahtengah kehidupan masyarakat. Yang dimaksud dengan pelayanan pastoral yang relevan/kontekstual disini adalah bagaimana pendampingan pastoral dapat menerapkan fungsi membimbing (guiding), menopang (sustaining), membedayakan (empowering) dan fngsi pastoral lainnya untuk memampukan para pecandu narkoba menyadari setiap sikap dan tindakan yang tidak baik terkait dengan penyalahgunaan narkoba yang dilakukannya. ${ }^{25}$ Sebagaimana telah disebutkan diatas bahwa perilaku kecanduan narkoba berkaitan dengan suara hati yang menyebabkan terjadinya kemerosotan moral oleh karena mengabaikan suara hati.

\section{Kesimpulan}

Beberapa defenisi tentang suara hati memperlihatkan kepada kita sebuah pemahaman bahwa di dalam diri setiap orang didapati pengetahuan akan kualitas moral yang meliputi perasaan benar atau salah dalam melihat sesuatu yang harus dipertanggungjawabkan. Juga adanya pengetahuan di dalam batin untuk membedakan tindakan yang benar dan salah secara moral. Suara hati ada di dalam batin terdalam manusia yang mengungkapkan bahwa di dalam hati manusia ada suara yang kecil yang mengarahkan manusia untuk melakukan yang baik dan mengelakkan yang jahat. Alkitab Perjanjian Lama menyatakan bahwa ada pengetahuan akan yang baik dan yang jahat dalam mengingat dan memelihara hukum Allah. Perjanjian Baru juga memperlihatkan peranan suara hati

\footnotetext{
${ }^{25}$ Howard Clinibel, Tipe-tipe Dasar Pendampingan dan Konseling Pastoral, Jakarta dan Yogyakarta: BPK Gunung Mulia dan Kanisius. 2002, hal17
}

yang berfungsi sebagai penilai tindakan benar dan salah pada masa lalu dan sekarang. Maka dapatlah disimpulkan bahwa peranan suara hati dapat dipakai dalam melaksanakan pendampingan pastoral kepada para pecandu narkoba untuk membimbing mereka guna menyesali dan menyadari keberadaannya dan tindakantindakan menyalahgunakan narkoba adalah salah dan tidak baik bagi kehidupan mereka. Dengan kesadaran ini diharapkan proses rehabilitasi akan memulikan kehidupan mereka.

\section{Daftar Pustaka}

[1]Alfred M.Rehwinkel, "conscience" dalam everett F, Harisson (Ed), Bakers's Dictionary of Theology, (Michigan: Baker Book House, 1985.

[2] Arimurthy, Hati Suci, Hati Nurani, dalam Ensiklopedi Nasional Indonesia, Jilid 6, (Jakarta: PT. Cipta Adi Pustaka, 1989.

[3]Bernard Lohse, Martin Luther : An ntroduction to His Life and Work, Philadelphia : Fortress Press, 1986.

[4]Bertens,K Etika , Jakarta: Penerbit PT Gramedia Pustaka Utama, 1993.

[5]Charles V Gerkin, Konseling Pastoral dalam Transisi, BPK Gunung MuliaKanisius :1999.

[6]Hasan Shadily, dkk (ed) dalam Ensiklopedi Indonesia Vol.6,Jakarta: PT Ichtiar Baru-Van Hoeve, t.th

[7] Hans Conzelman, An Outline of the Theology of New Testament, London :SCM Press Ltd, 1968/1969.

[8]H.Soekahar, Hati Nurani , Malang: Penerbit Gandum Mas, 1989.

[9]Heiko A. Oberman, Luther : Man between God and Devil, New Haven, London: Yale University Press, 1989.

[10] John Macquarrie, "Conscience" A Dictionary of Christian Ethics, London :SCM Press Ltd. 1984. 
[11] Newman JR, Barclay M, Kamus Yunani-Indonesia, Jakarta : BPK Gunung Mulia, 1993.

[12] Philip Babcock Gove (ed), Webter's Third New International Dictionary Of The English Language Unabridge,

[13] Soekahar, Hati Nurani, Flores: Penerbit Nusa Indah, 1983.

[14] Springfield, USA : G \& C Meriam Company, 1996.

[15] Stephen Tong, Roh Kudus, Suara Hati dan Setan, Jakarta : Lembaga Reformed Injili Indonesia, 1997.

[16] The Compact Edition of the Oxford English Dictionary, Vol.I, (Oxford: the Oxford University Press, 1971.

[17] Verne H.Fletcher, Lihatlah Sang Manusia, Suat Pendekatan Dasar pada Etika Kristen Dasar, Jakarta: BPK Gunung Mulia, 2007.

[18] Yohanes Calvin, Instutio Jakarta: BPK Gunung Mulia, 1985.

[19]https://www.kompasiana.com/sn/54f7ce 33a333112b6f8b4ecc/mengapa-pecandunarkoba-sulit-berhenti

[20]https://news.okezone.com/read/2014/10/ 31/338/1059246/narkoba-kini-jadi-gayahidup-pemuda

[21]https://jurnal.uns.ac.id/habitus/article/vie w/18860/14964, hal 92

[22] https://megapolitan.kompas.com/read/20 19/03/25/10215681/bnn-sepanjang-20182-juta-mahasiswa-dan-15-juta-pekerjaterlibat-narkoba. 